\title{
COESÃO E COERÊNCIA NO TEXTO ARGUMENTATIVO EM DEFESA DA LÍNGUA PORTUGUESA PUBLICADO POR JOSÉ PACHECO PEREIRA
}

\section{ARTIGO ORIGINAL}

MALDONADO, Gabriel Orlando Quiñones ${ }^{1}$

MALDONADO, Gabriel Orlando Quiñones. Coesão e coerência no texto argumentativo em defesa da Língua Portuguesa publicado por José Pacheco Pereira. Revista Científica Multidisciplinar Núcleo do Conhecimento. Ano 05, Ed. 08, Vol. 02, pp. 36-43. Agosto de 2020. ISSN: 2448-0959, Link de acesso: https://www.nucleodoconhecimento.com.br/letras/coesao-e-coerencia

\section{RESUMO}

O presente artigo fundamenta-se na área da Sociolinguística Interacional e apresenta uma análise de trechos do texto argumentativo publicado por José Pacheco Pereira "O vírus que atacou a língua portuguesa". Analisou-se fragmentos do texto para interpretar a coesão e coerência e apresenta-se a justificação dos seus argumentos no percurso da leitura deste artigo. Nesta iniciativa, os resultados revelaram a interpretação pragmática que teve o texto com a pandemia do COVID-19.

${ }^{1}$ Pós-doutor em Educação com investigação em Sociolinguística Musical Brasileira pela Universidade Virtual de Estudos Superiores - UNIVES no México (2020); Doutor em Ensino da Língua Portuguesa pela Bircham Internacional University em Madrid Espanha (2018); Mestre em Línguas, Culturas e Sociedades em Ambientes Multilíngues - Francês Língua Estrangeira pela "Université des Antilles" em Martinica (M1-2016 / M2-2018); Pós-graduado (Especialização) em Estudos de Língua Portuguesa: Investigação e Ensino pela Universidade Aberta de Portugal (2014): Graduado em Línguas Modernas, habilitação em Português e Francês, pela Universidad de Puerto Rico - Recinto de Río Pedras (2009). 
Palavras-chave: Sociolinguística Interacional, texto argumentativo, coesão, Língua Portuguesa, acordo ortográfico.

\section{INTRODUÇÃO}

Para esta análise, escolheu-se o texto argumentativo publicado por José Pacheco Pereira intitulado de "O vírus que atacou a língua portuguesa", porque se acolhe na temática do seminário Sociolinguística Interacional. Há vários anos que o senhor Pereira luta de forma constante contra o Acordo Ortográfico de 1990, doravante AO90. Ele sempre esteve em desacordo com o AO90. No seu artigo, ele refere-se ao Acordo como "acordês", o que pode gerar uma situação de confusão. Essa confusão levoume a procurar a definição da palavra "acordês", mas não achei nada relevante.

A palavra mais próxima foi acordes, sem circunflexo, referente aos acordes musicais. Na minha opinião, a língua é melodia, mas, neste caso, é dissonância, sem melodia, sem acordes. A palavra, também, desperta a atenção do leitor. À primeira vista, a palavra cumpriu o seu primeiro objetivo, cativar ao leitor. Em segundo lugar, a palavra apresenta ar de confusão e desse jeito encaminha-te a refletir sobre o pensar do autor: o desacordo ortográfico. Este texto argumentativo foi tão interessante que decidi analisá-lo e procurar a sua justificação e coerência.

\section{COERÊNCIA}

Coerência é o atributo textual/discursivo pelo qual as asseverações que o compõem se referem ao mesmo fato. Para que um texto/discurso seja coerente, as suas asseverações devem focar-se em um assunto e deve responder ao nosso conhecimento do dia a dia e da nossa realidade. Às vezes, o receptor poderia não ter experiência ou conhecimento acerca dos argumentos ou temas em discussão, o que levá-lo-ia à perda do interesse em finalizar a conversa ou a leitura. Os textos/discursos fornecem novas informações em cada enunciado/frase, mas os enunciados/frases deixam de ser consistentes se não se referirem à um assunto em comum. Segundo Lopes (2009, p. 242): "é geralmente aceito que estabelecer coerência é um aspecto central da compreensão do discurso; portanto, processar o significado do discurso 
envolve recuperar as relações de coerência que integram as proposições individuais expressas ao longo do texto".

\section{COESÃO}

Além de consistentes, as asseverações de um texto devem estar conectadas ou coesas entre si. Assim, duas asseverações coerentes podem não constituir um texto se a sua relação gramatical for incorreta. Coesão é, portanto, o atributo a partir do qual as asseverações de um texto estão vinculadas corretamente de um ponto de vista lexical e gramatical. A coesão se preserve nos textos a partir de procedimentos diversos que podem ser lexicais se atenderem às palavras e os seus significados, aos aspetos gramaticais e aos diversos recursos que forem utilizados. Nesse contexto, assevera Fonseca (1994, p. 8), que: "consubstancia-se, assim, a textura nos traços que fazem de um produto verbal um todo semântico unificado, como tal funcionando globalmente numa situação de comunicação, em que se inscreve por forma adequada".

\section{JUSTIFICAÇÃO}

A justificação pode ser um tipo de alinhamento aplicado às linhas de um texto para fazer com que cada extremidade corresponda ao pensamento inicial da declaração. Procura-se justificar o raciocínio individual ou coletivo, ou, ainda, as experiências expressas na afirmação ou no texto em geral. Para Lopes (2009, p. 242), a justificação deve ser compreendida a partir de uma relação de coerência pragmática, e, dessa forma, a fim de que essa relação seja caracterizada, o autor enfatiza as diferenças relacionais entre causa e justificação. Parte de textos curtos e argumenta que: "há evidências empíricas, em termos de comportamento sintático e prosódico, de que um relato da relação Justificativa requer uma sequência de dois atos de fala, e apontarei que essa relação ocorre em diferentes tipos de textos argumentativos". 


\subsection{A CAUSA E EFEITO}

A ação de um indivíduo está relacionada, de alguma forma, à algo que o leva a agir. O efeito é o resultado, fim, consequência, conclusão acerca do que é derivado de uma causa. Isso ocorre porque todo fenômeno tem algo que o gera, já que nada acontece do nada, mas o que sai sob a percepção da causa é o que é conhecido como efeito. Portanto, todo evento tem uma causa, pois tudo o que acontece está vinculado à um processo de interação, sendo os primeiros eventos a causa e os segundos, por sua vez, representam os efeitos. Segundo Lopes (2009, pp. 250-251),

... Coletei um conjunto de exemplos mostrando que a mesma relação de coerência da Justificação pode ser marcada por diferentes conectivos no português europeu contemporâneo: porque, pois, visto que, dado que, já que, uma vez que... Excerto 1: "Já não ponho livros em cima da mesa, romances, poemas, ensaios, porque quanto mais conhecido e criativo é o autor, menos usa o "acordês"."

$\mathrm{Na}$ análise do excerto 1, evidencia-se que quanto mais conhecido e criativo for o autor, menos usará o "acordês", uma vez que as obras a serem criadas irá considerar o vínculo construído com o leitor, que dispensa o "acordês".

\subsection{OS ADVÉRBIOS}

Segundo Lopes (2013, p. 11), "os advérbios agora, então, logo, sempre, ainda, já, enfim funcionam sintaticamente como modificadores de predicado, expressam valores temporais ou aspectuais e contribuem para o conteúdo proposicional dos enunciados que os acolhem". O autor propõe dois excertos para exemplificar essa situação:

Excerto 2. "Eu não desisto, porque há ainda muita coisa a fazer contra o Acordo".

Excerto 3. "Depois ajuda-se por todos os meios os que explicitamente são contra o Acordo, de modo a criar um cáucus ...".

$\mathrm{Na}$ análise do excerto 2, o fato de que "há muita coisa a fazer contra o Acordo" é a causa do fato que ele ainda não desiste. $O$ advérbio, ainda, modifica o predicado, 
expressando o valor temporal de uma ação inconclusa, neste caso "há muita coisa a fazer contra o Acordo".

$\mathrm{Na}$ análise do excerto 3, continuando a evolução do texto argumentativo, o autor usa o advérbio "depois" para indicar continuidade, acompanhado no mesmo enunciado do outro advérbio "de modo". Divulgando que depois de receber o apoio dos que são contra o Acordo, terá uma atitude de modo a criar um cáucus. Na investigação de informações sobre o autor do texto, descobri que ele luta há muitos anos contra o Acordo. Então esse advérbio dá peso às suas palavras. O valor temporal de "ainda" traz o peso da luta constante de anos atrás diretamente ao momento em que o texto foi escrito.

\subsection{O PARTICÍPIO PASSADO}

Todos os particípios passados dos verbos -ar terminam em -ado, enquanto os particípios passados dos verbos -er e -ir geralmente terminam em -ido. Exemplos: falar-falado, comer- comido, ouvir-ouvido. Alguns verbos -er e -ir têm particípios do passado irregulares. Aqui estão alguns dos mais comuns: (abrir: aberto/ cobrir: coberto/ dizer: dito/ escrever: escrito/ fazer: feito/ pôr: posto/ ver: visto/ vir: vindo). Alguns verbos têm duas formas de particípio, um regular e outro irregular. A forma irregular é usada com os verbos auxiliares ser e estar. A forma regular é usada com os verbos auxiliares ter e haver.

Quando um particípio passado é usado como adjetivo, ele concorda com o número e gênero que modifica. Também é usado, nesse contexto, o verbo estar + particípio passado para expressar um estado ou condição resultante de uma ação anterior. Segundo Lopes (1996, p. 366) o particípio passado permite a descrição do estado que é subsequente à culminação, "mas pressupõe essa mesma culminação, esse ponto fronteira. O evento descrito pela oração principal é posterior ao evento culminado que a oração participial pressupõe: daí a interpretação sequencial". Exemplo: "A língua é uma coisa viva, e o "acordês" é uma língua morta". 
$\mathrm{Na}$ análise do excerto 4 , temos um estado subsequente que é "a língua é uma coisa viva" à culminação do excerto que é "e o "acordês" é uma língua morta". O sentido que trouxe é que o Acordo mata a língua e a língua é uma coisa viva.

\subsection{OS CONECTORES}

Segundo Lopes (2005, p. 17), "os conectores são outro instrumento fulcral de coesão textual/discursiva. Incluímos sob a designação de conectores quer as tradicionais conjunções (e, ou, mas, porque, quando, etc.)". Continua a sua análise afirmando que a situação é presente: "[...] quer expressões adverbiais e preposicionais com função conectiva (finalmente, por fim, em suma, com efeito, de facto, deste modo, consequentemente, assim, daí, ao invés, pelo contrário, no entanto, etc.)" (idem).

Excerto 5. "Por detrás destas publicações está uma série de acordos diplomáticos que, ou estão a ser ilegalmente aplicados, ou foram ratificados e metidos na gaveta, com explícitas declarações de que são para meter na gaveta, ou, por fim, não foram aprovados pelos países que deveriam tê-los incorporado na legislação nacional" (LOPES, 2005, p. 17).

$\mathrm{Na}$ análise do excerto 5, vê-se que o conector 'ou' é usado três vezes pelo autor. Nesse caso, facilita a construção do sentido de vários acontecimentos por detrás das publicações de acordos diplomáticos.

\section{SOCIOLINGUÍSTICA INTERACIONAL E A PRAGMÁTICA INTERCULTURAL}

Neste texto e em entrevistas registradas em internet, Pereira procura atirar a atenção da comunidade portuguesa. No seu percurso, ele tem lutado fielmente contra o Acordo Ortográfico de 1990 a partir de atos em defensa da sociedade e da língua portuguesa, como aponta o excerto 6: "E, como ser vivo, a língua e a sua ortografia evoluem todos os dias, traduzindo o dinamismo dos povos e da sociedade onde é falada e escrita". Explica Tannen (2005, p. 208) que:

A análise de SI visa, em primeiro lugar, explicar como a linguagem funciona para criar significado na interação e, em segundo lugar, como 
um dos muitos elementos que contribuem para os resultados quando membros de culturas diferentes se encontram em contextos em que a linguagem é um grande meio de negociação.

Fonseca (1992, p. 48) expõe que "a compreensão do texto se desenvolve na base desta interação entre o verbalizado e o universo de conhecimento do receptor. Depende da capacidade que revele o receptor de ligar os factos, os acontecimentos." No texto que aqui analiso, a palavra "acordês" teve um impacto significativo. Ao ler a palavra, criam-se dúvidas, surgem questionamentos, todos referentes ao valor da palavra e ao que o autor queria expressar. Em geral, os textos/discursos argumentativos pretendem conquistar o seu leitor/receptor. Com isso, os argumentos são apresentados em apoio a um pensamento ou ponto de vista. O locutor/ emissor do texto/discurso depende do desenvolvimento racional (com contribuições de evidência, os elementos estabelecidos de conexão, coerência, reflexões, opiniões, experiências, entre outros) e usa vários gêneros discursivos, como narração, descrição e exposição.

No contexto da argumentação discursiva, considera-se que ela tem como posição inicial uma abordagem que não é compartilhada internacionalmente, portanto, razões a favor e contra da argumentação proposta serão constantemente obtidas. A argumentação tem como abordagem difundir uma convicção a partir da opinião do locutor/emissor para poder impactar o interlocutor-leitor/receptor e que a mensagem seja admitida ou refutada, de acordo com o modo de pensar de cada um. Rodrigues (2007, p. 9), no seu artigo "Processos cognitivos e estratégias de comunicação", explica que:

A interação discursiva é uma atividade que seres humanos realizam na presença física uns dos outros, dessa presença decorrendo para os que nela tomam parte o estatuto de participantes. É porque a presença física é o fator primeiro e fundamental da prática discursiva que todas as outras modalidades de prática discursiva têm na atividade conversacional o seu modelo e o seu fundamento. Em qualquer das outras modalidades discursivas, como por exemplo na correspondência epistolar, telefônica ou telemática, na escrita e na leitura de obras literárias ou de qualquer outra modalidade de discurso escrito, só podemos entender o sentido daquilo que escrevemos ou lemos porque pressupomos a presença física de interlocutores. 
Assim: "Cada uma dessas outras modalidades de prática discursiva depende de dispositivos técnicos que não conseguem assegurar a totalidade das dimensões da presença física envolvidas na atividade conversacional face a face" (RODRIGUES, 2007, p. 9).

\section{CONCLUSÃO}

O texto argumentativo de Pereira, na minha opinião, cumpre com os processos estruturais de coesão e coerência. Os seus argumentos foram apresentados e justificados no percurso da leitura. Por outra parte, o autor tem várias apresentações registadas em vídeo que podem ser procuradas na internet. Já com isso, o autor tem uma trajetória de interação com uma comunidade que apoia ou não a eliminação do Acordo Ortográfico de 1990. No início do texto, ele apresentou em uma oração um argumento que mostra o apoio a sua alegação. No excerto 7, vemos que 0 autor escreveu a palavra "atuais", usada antes do AO90, por enquanto ele continua empregando a ortografia usada antes do AO90. Aqui não se faz uma análise de palavras escritas no texto, mas usa a escrita aplicada antes do AO90 para autossustentar a sua argumentação.

É, também, outro jeito de se mergulhar na comunidade que apoia a derrogação do AO90. Para concluir, analiso o argumento de José Pacheco Pereira. O texto apresenta o tema a partir do argumento de que há "um vírus que ataca a língua portuguesa". O autor aproveita a situação global do vírus para dar mais impacto à argumentação que expõe na sua mensagem. $\mathrm{O}$ autor quer mostrar que a língua portuguesa foi ferida por um vírus pior do que o Coronavírus, devido aos efeitos sociais e culturais que a implementação do Acordo Ortográfico de 1990 trouxe. O autor expressa que o Acordo é impopular. A sensação de que não é popular é porque os outros países de língua portuguesa, a grande maioria dos autores ou criativos famosos, não usam o acordo. A conclusão do autor é a oração a seguir "A língua portuguesa precisa de nós. E não se esqueçam deste facto: o Acordo e impopular". Nessa conclusão, o autor faz referência ao sentido de que o acordo é impopular, já que ninguém segue as regras e continuam a usar a "língua viva", a língua popular, a língua que foi, é e será sustentada pela sociedade e não pelas academias, nem os governos. 


\section{REFERÊNCIAS}

FONSECA, J. Coerência e coesão nas unidades linguísticas. In: FONSECA, J. (Org.) Linguística e texto/Discurso: teoria, descrição, aplicação. Lisboa: Ministério da Educação/ Instituto de Cultura e Língua Portuguesa, 1992.

FONSECA, J. O lugar da Pragmática na Teoria e na Análise Linguísticas. In: FONSECA, J. (Org.). Pragmática linguística. Porto: Porto Editora, 1994.

LOPES, A. C. M. Texto e coerência. Revista Portuguesa de Humanidades, v. 9, n.1/2, p.13-33, 2005.

LOPES, A. C. M. Interfaces. In: SILVA, F. et al. (Eds.). Textos Selecionados. Coimbra: APL, 2013, p. 3-20.

LOPES, A. C. M. Tempo, aspecto e coesão discursiva. Actas do XI Encontro Nacional da Associação Portuguesa de Linguística, v. 3, p. 351-371, 1995.

LOPES, A. C. M. Justification: a coherence relation. Pragmatics, v. 19, n. 2, p. 241252, 2009.

PEREIRA, J. P. O vírus que atacou a língua portuguesa. 2020. Disponível em: https://www.publico.pt/2020/05/09/opiniao/opiniao/virus-atacou-lingua-portuguesa1915735 Acesso em: 9 jul. 2020.

RODRIGUES, Adriano Duarte. Processos cognitivos e estratégias de comunicação. Revista do Centro de Estudos Judiciários, v. 7, p. 1-27, 2007.

TANNEN, Deborah. Interactional sociolinguistics as a resource for intercultural pragmatics. Intercultural Pragmatics, v. 2, n. 2, p. 205-208, 2005.

Enviado: Julho, 2020.

Aprovado: Agosto, 2020. 